\title{
SELF-REALIZATION, DEMOGRACY, AND FREEDOM OF EXPRESSION: A REPLY TO PROFESSOR BAKER
}

\section{MARTIN H. REDISH $\dagger$}

There is something of an irony in Professor Baker's decision to respond to my theory of the value of free speech. Of the modern free speech theorists with whom I differ-and the number is considerable ${ }^{1}$-Professor Baker is in many ways the one with whom I have the fewest fundamental differences. Indeed, much of my article was structured as a defense to an anticipated attack by those theorists who believe that the sole, or at least primary, function of the free speech guarantee is to further the political process. ${ }^{2}$ Professor Baker is undoubtedly the one least concerned with this issue. Instead, he emphasizes, as I do, the need to focus on development of the individual as the ultimate value of the first amendment guarantee. $^{3}$ Yet my differences with Professor Baker are not insignificant. For, as $\mathrm{I}$ assert in my article, $\mathrm{I}$ believe that Baker fails to recognize the logical implications of his own fundamental assumptions. ${ }^{4}$

Professor Baker's response to my article consists of both a critique of my theory and a defense of his theory against the criticisms I made of it. In an important sense, however, the two are inextricably intertwined.

Baker begins his comment by correctly noting our significant difference over the outcome in First National Bank of Boston $v$. Bellotti: ${ }^{5}$ I believe it was rightly decided, whereas he believes the

$\dagger$ Professor of Law, Northwestern University. A.B., 1967, University of Pennsylvania; J.D., 1970, Harvard University.

1 See generally Redish, The Value of Free Speech, 130 U. PA. L. REv. 591 (1982). In the article, I criticize the theories of Judge Bork and Professors Blasi and Meiklejohn, as well as that of Professor Baker.

2 See id. 596-601.

3 See Baker, Scope of the First Amendment Freedom of Speech, 25 U.C.L.A. L. REv. 964, 966, 990-96 (1978) [hereinafter cited as Freedom of Speech]. Baker notes that my approach "corresponds closely to [his] presentation of a liberty theory of the first amendment." Baker, Realizing Self-Realization: Corporate Political Expenditures and Redish's The Value of Free Speech, 130 U. PA. L. Rev. 646, 658 (1982) [hereinafter cited as Realizing Self-Realization]. Actually, the origins of my self-realization theory can be found in an earlier article, Redish, The First Amendment in the Marketplace: Commercial Speech and the Values of Free Expression, 39 GeO. WaSh. L. REv. 429 (1971).

4 Redish, supra note 1 , at $620-21$.

5435 U.S. 765 (1978). 
decision was wrong. ${ }^{\circ}$ This difference flows from our respective beliefs concerning the relevance for first amendment purposes of the receipt, as opposed to merely the expression, of information, opinion, and thought. Because I firmly believe that the value of selfrealization, as I define it, ${ }^{7}$ may be fostered as much by the receipt of expression as by the act of expressing, I conclude that the source or motivation of the expression is largely irrelevant. Baker, on the other hand, believes that the source is all important. ${ }^{8}$ Baker apparently believes that this difference of opinion flows from the differing ways in which we structure and develop the self-realization value, and therefore that he can establish that his emphasis on the source of expression is the more appropriate approach by demonstrating that my structural analysis is inaccurate or unfounded. ${ }^{9}$

Not surprisingly, I find Baker's critique of my theory most unpersuasive. But perhaps more importantly, Baker's main fallacy is his assumption that acceptance of his own theory justifies his emphasis on the source of expression. As I attempted to make clear in my article (apparently unsuccessfully for Baker), his emphasis on source does not follow logically from his own theoretical assumptions. ${ }^{10}$ At the risk of inserting an artificial distinction into Baker's response, I will discuss separately his criticism of my theory and his defense of his own theory. ${ }^{11}$

\section{Baker's Critique: The Relevance of Democratic Values to Free Speech Theory}

Unlike Baker, who supports his normative assertions about the value of self-realization with little more than conclusory contentions, ${ }^{12} \mathrm{I}$ attempt to justify recognition of its centrality by reasoning from the existence of our democratic system. Democracy, I argue, is not an end in itself; it is, rather, a means of achieving broader values. After considering and rejecting certain conceivable values thought to be fostered by a democratic system, ${ }^{13}$ I settle upon two-the inherent value in allowing individuals to control their own

6 See Baker, Realizing Self-Realization, supra note 3, at 655-58.

T See Redish, supra note 1, at 593.

8 See Baker, Realizing Self-Realization, supra note 3, at 652.

I See id. 658-67.

10 See Redish, supra note 1 , at $620-21$.

11 There is, however, some inevitable overlap in the two discussions.

12 See, e.g., Baker, Freedom of Speech, supra note 3, at 991-92.

13 The primary conceivable value that $I$ consider and reject is the practical benefit of "better" or more efficient government. See Redish, supra note 1, at 602. 
destiny, and the instrumental value in developing individuals' mental faculties so that they may reach their full intellectual potential-and group these two values under the broader heading "self-realization." 14 Because speech unrelated to the actual conduct of democracy may aid self-realization as well as speech that concerns the operation of the political process, I conclude that the reach of the first amendment must be considerably broader than that suggested by such scholars as Bork, Blasi, and Meiklejohn. ${ }^{16}$

Baker takes issue with my reasoning. I find this surprising, because Baker himself, unlike the other commentators with whom I disagree, ultimately arrives at much the same destination that I do. ${ }^{16}$ Since he took the time to critique my reasoning, however, I feel it appropriate that I take the time to respond to his criticism.

Baker's criticism takes the following course. First, he rejects my conclusion that democracy is designed to foster the developmentof-faculties value. Then, having left me only the self-rule value with which to cover myself, he proceeds to remove even that bit of covering by concluding that, although self-rule is indeed a value of a democratic system, my method of viewing free speech as a means of fostering that value is improper. ${ }^{17}$

In support of his first point, Baker argues that:

Although democracy may further the "development of the individual's human faculties," a concern with selfdevelopment does not in any obvious way require a democratic political order. More relevantly .... one might accept democracy for reasons other than a concern for individuals' development of their faculties-for example, because of the importance we place on self-rule. ${ }^{18}$

In this statement, Baker effectively asserts that democracy is not needed for self-development, and that self-development is not needed for democracy. Whatever the merits of the latter comment, ${ }^{19}$ the former is, I believe, plainly incorrect. As Mill argued, any development of mental faculties in a nondemocratic setting is inherently and fatally incomplete. ${ }^{20}$ Even in the most benevolent dictatorship, in which individuals might be free to express them-

14 Id. 593, 602-03.

15 Id. 596-619.

16 See supra note 3 and accompanying text.

17 See Baker, Realizing Self-Realization, supra note 3, at 660-68.

18 Id. 660 (footnote omitted).

19 See infra text following note 22. (1882).

$20 \mathrm{~J}$. Mill, Consmerations on Representattve Government 62-63, 69-80 
selves through art, music, or literature, the inherent limitation on the individual's ability to employ these devices as a means of attacking the government and to take part in collective decisionmaking would inescapably stunt full and free development. Mill wrote, in the final paragraph of On Liberty, that:

The worth of a State, in the long run, is the worth of the individuals composing it; and a State which postpones the interests of their mental expansion and elevation, ... . a State which dwarfs its men, in order that they may be more docile instruments in its hands even for beneficial purposes-will find that with small men no great thing can really be accomplished ...."21

For believers in realization of an individual's intellectual potential, then, Mill was certainly correct when he urged that a "benevolent dictatorship" is a contradiction in terms. ${ }^{22}$

As to Baker's second point, it is true, I suppose, that one could choose to adopt a democratic system without concern for the intellectual development of the individual-although, as Baker recognizes, such a benefit will inherently flow from use of such a political system, whether intended or not. But whether or not one could logically choose to adopt a democratic system without concern for individual development, classical democratic theorists have long recognized the resulting benefits for individual mental, intellectual, and human development as one of the primary values of democracy. ${ }^{23}$ This normative principle is so ingrained in traditional democratic theory that it is reasonable to suggest that it be deemed a value behind the longest living democratic system of modern times. ${ }^{24}$ Moreover, because the effective functioning of a democracy

21 J. MrL, ON Lmenty 117-18 (1947) (1st ed. London 1859) (emphasis in original).

22 See J. MIr, supra note 20, at 62-63.

23 See Redish, supra note 1, at 603. As Bachrach argues, "[c]lassical [democratic] theory . . . is based on the supposition that man's dignity, and indeed his growth and development as a functioning and responsive individual in a free society, is dependent upon an opportunity to participate actively in decisions that significantly affect him." P. BACFrace, ThE ThEORY OF DEMOcratic EIITISM: A CRITIQUE 98 (1967). Bachrach cites "the belief of Rousseau, Kant, Mill, Lindsay, and others, that man's development as a human being is closely dependent upon his opportunity to contribute to the solution of problems relating to his own actions." Id. 99.

24 Modern elitist democratic theory has questioned the viability of many of the classical assumptions, but the elitist theorists generally do not question the normative element of the classical theorists' belief in individual development, merely its feasibility. See Redish, supra note 1, at 608-09. In response to the elitists' contentions, modern commentators have suggested recognizing that the individual development value may be achieved through means other than involvement in the traditional political process. See P. Bachracr, supra note 17; Redish, supra note 1, at 609-10. This is entirely consistent with the position taken in my article. 
requires that individuals employ their mental faculties in making political choices, it is not a significant leap to suggest that adoption of a democratic system implies a belief in the value of individual mental development. There is no reason to suppose-as Baker implies-that the values of self-rule and self-realization are in any way mutually exclusive as justifications for our adoption of a democratic system.

Once Baker believes that he has disposed of the self-development value, he attempts to demonstrate that my link between the self-rule value and the free dissemination of information is unfounded. My theory is, simply, that performance of the function of self-rule is fostered by the receipt of information that enables the individual to make life-affecting decisions in a more informed fashion. ${ }^{25}$ Free dissemination of information, in other words, helps inform the individual of the possible benefits and risks of each of the courses of action that he or she can take. It is difficult for me to understand how anyone could reject such intuitively appealing reasoning. The concept of self-rule definitionally implies that at every turn an individual may make one of several choices in governing his or her life, and information relevant to those various options can only foster the effective use of the individual's decisionmaking power. ${ }^{26}$

Baker offers three criticisms of my theory: (I) that "self-rule and democracy can and do operate without full or complete information"; ${ }^{27}$ (2) that, "even if supplying information to the listener usually promotes self-rule, this 'indirect' support does not distinguish the information's contribution from the contribution made by various other resources and opportunities, such as food, shelter, health care, and employment and educational options," or a right of access to government-held information; 28 and (3) that "it remains an open empirical and normative question whether this additional information [provided by corporate speech] actually promotes rational, intelligent self-rule." ${ }^{29}$ Baker even suggests that such widespread protection of the dissemination of information "might in fact detract from self-rule by contributing to information overload, by supplying an ideologically unbalanced and distorted background, or by promoting simplistic thinking." 30 None

25 See Redish, supra note 1, at 604, 618.

26 See 1 M. AdLER, ThE IDEA OF FREEDOM 112 (1958).

27 Baker, Realizing Self-Realization, supra note 3, at 661.

28 Id. 662.

29 Id. 663.

$30 \mathrm{Id}$. 
of these points, however, effectively impairs recognition of the importance of free speech protection to the goal of self-rule.

Baker's first point is quite probably the least persuasive of the three. That democracy or self-rule can operate without complete information is beside the point. The questions that Baker should -but does not-ask are whether self-rule's operation is likely to be improved by an increase in the flow of relevant information, and whether, correspondingly, that operation is likely to be impaired by a decrease in information flow. In the political realm, leading commentators ${ }^{31}$ and the Supreme Court ${ }^{32}$ have assumed that people's decisions in the voting booth are impaired to the extent that they are unable to obtain information about the candidates, such as their stands on the issues. The accuracy of this conclusion easily can be seen by imagining an election in which no one, including the candidates themselves, was allowed to say anything about the relative qualifications or positions of the competing office seekers. The public's performance of the democratic function in such an election would be a mockery. Although I suppose that the level of information could never be "complete," that does not mean that the performance of the self-rule function would not be significantly undermined if we reduced protection for the dissemination of whatever information is available. ${ }^{33}$

Baker's second point-that other resources also contribute to self-rule-sounds vaguely reminiscent of the argument of Judge Bork that there is no rational means to distinguish the values de-

31 See, e.g., A. Meiknejomn, Poltimcal Freedom (1960) (expanded version of Meiklejohn's Free Speech (1948)).

32 See, e.g., Monitor Patriot Co. v. Roy, 401 U.S. 265 (1971); New York Times Co. v. Sullivan, 376 U.S. 254 (1964).

${ }^{33}$ Baker argues that "[a]s long as the first amendment protects a free press and the individual's right to speak, most information and argument that the corporation would subsidize will be made available anyway .... Baker, Realizing SelfRealization, supra note 3, at 663. But we can never be certain that "enough" information has been made available, since we can never be sure how and when people obtain their information. The Supreme Court has generally been unmoved by arguments that a particular restriction on expression still leaves room for most communication. See, e.g., Mills v. Alabama, 384 U.S. 214 (1966); Schneider v. State, 308 U.S. 147 (1939); cf. infra text following note 33 . In any event, if one accepts that protecting both the dissemination and the receipt of information is a valid and important function of the first amendment, Baker's suggestion that denying protection to profit-oriented speech would leave most information available is irrelevant. The same could be said of a rule that people with red hair may not speak, or that a particular type of demonstration is not allowed. The question that must be asked is whether the distinction that Baker draws makes any sense. If we agree that the receipt of information serves a valuable first amendment interest and that even profit-oriented speech may further this value, there is no rational basis upon which to distinguish such speech; it is therefore no answer that such a limitation would leave "most" information available. 
rived from protection of most forms of expression and many forms

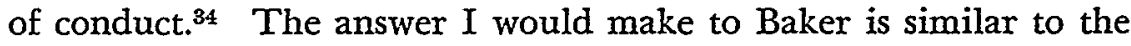
answer I gave to Bork: the primary basis of the distinction is that the framers chose to draw one, by framing the first amendment to protect only speech, and thereby relegating the liberty to undertake other forms of activity to the considerably reduced protection of the fifth amendment's due process clause. ${ }^{35}$ I also suggested that such a decision made good practical sense, because the potential harm flowing from speech generally is considerably less direct and acute than is the danger from action, and because speech and communicative activities are in general more likely to develop individuals' mental faculties. ${ }^{36}$

Baker's response is that, "[a]lthough there is an explicit constitutional judgment concerning the importance of freedom of speech, ... [t] the text of the Constitution does not itself show whether the first amendment's focus is on the provision of information or on the individual's freedom." 37 But Baker's second criticism does not really go to that issue, because the same argument could be directed at the liberty model: without food or shelter, a right of self-expression-or of anything else, for that matter-is meaningless. In structuring his "liberty" theory, Baker actually includes within the first amendment guarantee activity that is admittedly "conduct" and cannot rationally be defined as "speech," even though the explicit language of the amendment that he purports to interpret could not make it more clear that the protection is limited to "speech." Yet not even Baker extends the first amendment's protection to an obligation of governmental support. Although I might well agree with Baker that effective self-rule requires access to government-held information, education, food, and shelter, ${ }^{38}$ the need for such rights is totally irrelevant to the meaning and interpretation of the first amendment's guarantee of free speech. Rights

34 Bork, Neutral Principles and Some First Amendment Problems, 47 IND. L.J. I (1971), discussed in Redish, supra note 1, at 597-601.

35 Redish, supra note 1 , at 600 .

${ }^{36} \mathrm{Id}$. 601. Baker's second point ultimately goes much further than Bork, in that Baker fails to distinguish not only among different forms of liberty, but also between freedom from governmental restraint and the right to a governmental subsidy. The framers quite probably never considered providing constitutional rights to education, food, or shelter, but, if they had considered it, they could easily have distinguished those means of fostering self-rule from freedom of expression. Each of those methods requires affirmative governmental assistance; protection of free expression, on the other hand, simply requires the government not to act. The financial and administrative burdens that would be caused by constitutional protection for the items suggested by Baker would no doubt be substantial.

37 Baker, Realizing Self-Realization, supra note 3, at 662 .

38 Id. 665 . 
to information, education, food, and shelter would each require an additional constitutional amendment. But that, for whatever reason, ${ }^{39}$ the framers chose not to provide constitutional protection for every conceivable means of fostering self-rule does not imply that we should fail to recognize the importance to self-rule of the activity that they did choose to protect so thoroughly.

Baker's third criticism-that the additional information may not advance "rational, intelligent self-rule"-is no more persuasive. As I establish in my article, ${ }^{40}$ Baker's fallacy on this point is his assumption that the value of self-rule is limited to whatever he would label "rational, intelligent self-rule." 41 But such a limitation would totally undermine the concept, for to allow individuals to choose only what some external force determines is "rational" and "intelligent" is effectively to deprive them of self-rule.42 As for Baker's fear of an "information overload," if there could ever be such a thing, my only response is that I simply do not feel comfortable in deciding-or in having anyone else decide-at what point such an "overload" has been reached. Since we can never really know when "enough" information has been made available, ${ }^{43} \mathrm{I}$, for one, would much prefer to risk "too much" information than too little.

\section{Baker's Defense: The Fallacy of a "Source" Focus}

As noted earlier, it is puzzling that Professor Baker is so quick to dispose of my co-emphasis on the self-development value.44 For even if he is correct in his assertion that such a value is not logically implicit in the adoption of a democratic system, ${ }^{45}$ that value is nevertheless central to Baker's own theory. ${ }^{46}$ By so quickly disposing of the self-development aspect of my theory, however, Baker is

30 See supra note 36 .

40 Redish, supra note 1 , at 618-19.

41 Baker, Realizing Self-Realization, supra note 3, at 663 .

42 It is, of course, true that for many activities the state may, and often does, constitutionally limit an individual's power of self-rule. But, as I showed in my article, the relevant point for first amendment purposes is that, for those activities in which we do allow the individual to make life-affecting decisions, it hardly makes sense to say that individuals have the authority to decide for themselves, but that we will allow or encourage only those decisions that are externally deemed "rational" or "intelligent."

43 See Redish, The Content Distinction in First Amendment Analysis, 34 Stan.

L. REv. 113, 130-31 (1981).

44 See supra text accompanying notes 1-3, 11-12.

45 As already noted, I do not believe that he is correct. See supra text accompanying notes 13-14.

46 See Baker, Freedom of Speech, supra note 3, at 966, 990-96. 
able to obscure much of my critique of his theory. One of my criticisms was that Baker refused to recognize that an individual's faculties may develop by the receipt, as well as by the dissemination, of communication. Even putting aside the developmental value to be gained from receipt of information relevant to the making of life-affecting decisions, ${ }^{47}$ there may be significant developmental value from reading a novel, short story, essay, or poem, or from viewing a play or film. Although one would hope that the communicator would benefit as well, there can be little doubt that the reader, viewer, or listener does so. Should it matter, then, whether the motivation of the communicator is to develop his or her faculties or to make a profit? If Baker were to acknowledge-as I would expect anyone must-that reading a novel or poem can advance self-realization, he would see that his emphasis on the source of the expression as the sole focus for determining the protection to be given to speech makes no sense.

Equally damaging to Baker's artificial limitation of his own "liberty" theory is, as I noted in my article, the impossibility of separating the profit orientation from the goal of self-realization. ${ }^{48}$ Baker still has failed to respond adequately to my examples of the welfare and social security recipients who wish to express dissatisfaction with cuts in their aid. His example of the worker whom, Baker suggests, "the market does not compel . . . to seek more," 49 even if accurate, is not analogous to the individual who is totally dependent on entitlement programs that have been reduced or eliminated. In such a situation, the content of the individual's expression is as much dictated by "market forces" as is the advertising of a commercial enterprise; the former is no more likely to urge further cuts than the latter is to urge customers to purchase a competitor's product. Yet Baker would not deny protection to the speech of the welfare or social security recipient, as well he should not. He analogizes my example of the creative advertiser ${ }^{50}$ to " the pianist who ... has a right to engage in her activity but no right to demand an economic arrangement that pays for her expressive activities." 51 But this comment views the situation in reverse. No one is arguing that the first amendment somehow gives the pianist the right to demand an economic arrangement; the point, rather, is that the mere fact that one has entered into an economic

47 See Redish, supra note 1, at 620-21.

48 See id. 621-22.

49 Baker, Realizing Self-Realization, supra note 3, at 672 n.87.

50 Redish, supra note 1 , at 621 .

51 Baker, Realizing Self-Realization, supra note 3, at 672 n.87. 
arrangement should not automatically forfeit her-or her listeners' -right of free expression and self-development.

In response to my criticisms, however, Baker devotes most of his attention to the example of the political candidate, who, I suggested, may be oriented as much towards election in his or her speeches as the commercial advertiser is towards selling his or her product.52 Baker's intricate response seems to come down to this: election expenditures are an "investment ... in promoting particular views or values ..., not in achieving an economic return that is independent of the expressed values." 53 Baker obviously does not live in Chicago, for if he did he would have little doubt that, at least in certain elections, winning is considerably more important than "promoting particular views or values." ${ }^{54}$ Baker seems to think that the overwhelming majority of political candidates are much closer to Norman Thomas than they are to the typical "valueless" aldermanic candidate in Chicago, a conclusion that is, to say the least, far from empirically established.55 In any event, it seems to me that-ito focus for a moment on the candidate's supporters rather than the candidate-it is impossible to separate one's view of the validity of the candidate's "values" from the benefits one expects to receive from the candidate's election. How do we characterize, for example, a supporter's speech advocating election of his candidate because the candidate has promised tax relief? Is that speech the result of a "value," or simply an attempt to obtain an economic advantage?

The point of my discussion is simply to underscore the artificiality of the distinction that Baker attempts to draw. Indeed, Baker himself correctly recognizes that it is impossible to draw such a distinction with respect to a political candidate. He fails to recognize, however, the impossibility of drawing the distinction in the commercial situation, as well. But his greatest mistake is his assumption that anything should turn on the distinction, even if it could be drawn. I have no doubt that, even in elections in

52 Redish, supra note 1, at 621-22.

53 Baker, Realizing Self-Realization, supra note 3, at 673 (emphasis in original).

64 Baker argues that his point is more obvious with respect to third parties. Id. 675. But, even if that is correct, it does not provide an adequate explanation for protecting speech in the course of the considerably more common two-party race.

55 See R. Darf, Pluratist Demogracx in the United States: Conflitct AND CONSENT 131 (1967) ("[T]he mores of Congress, accepted by the leaders themselves, are perfectly clear ... : [the member's] own reelection comes first."). See also Perry, Noninterpretative Review in Human Rights Cases: A Functional Justification, 56 N.Y.U. L. REv. 278, 293 (1981) ("[F]or most [elected officials] few, if any, values rank as high as incumbency.") (footnote omitted). 
which a political candidate openly acknowledged that his or her sole goal was to win, any information that the candidate disseminated about his or her own qualifications or those of an opponent would be fully worthy of first amendment protection. This is because it makes no difference logically what the source of the expression is; whatever the source, the individuals who receive that information can put it to good use in exercising their "self-rule" function of selecting those who will make political decisions for them. The same can be said, I believe, of the commercial advertiser who supplies information and opinion that may enable the individual to perform his private self-ruling function more effectively. 